\title{
The effect of information and communication to revenue collection in selected hotels in Kigali
}

\author{
Henry John Musango ${ }^{1}$ and Claude Rusibana ${ }^{2}$ \\ ${ }^{1}$ School of Business and economic, Mount Kenya University, \\ Kigali, Rwanda \\ ${ }^{2}$ School of Business and economic, Mount Kenya University, \\ Kigali, Rwanda
}

\begin{abstract}
Revenue collection is an important goal set by most of the organizations to achieve profit maximization. The researcher examined the relationship of internal control system process and revenue collection in the hotel industry in Kigali, Rwanda based on selected hotelswhich were categorized under four or five-star classification by RDB. Niewiadomski (2013), identified that many hotels over the world disclosed weak internal control system process which affected revenue collection due to internal and external errors or frauds. To evaluate the effect of information and communication on revenue collection in selected hotels in Kigali city, the researcher gathered data from different individuals which consisted of qualitative and quantitative methods to give inferential statistics. The target population was 101 participants with a sample size of 69 employees from Marriot hotel and Lemigo hotel. The primary data was gathered through distribution of questionnaires. The data collected was statistically analyzed using SPSS version 26 software which produced a $\mathrm{R}$ square of 0.933 , a P-value of 0.326 and the regression analysis showed that when the independent variables were put to zero, the revenue collection had a coefficient of 4.214. The researcher found that a decrease in control activities by one unit would decrease revenue by 0.334 and an increase of an element in risk assessment would trigger an increase of revenue collection by 0.154 . The researcher reached a conclusion that internal control system process had an effect on revenue collection and there is need to improve the control activities, in particular segregation of duties, supervision and strengthening of internal audit function.
\end{abstract}

Keywords:

Internal Control System, Revenue Collection and Hotel or Hospitality Industry

\section{Introduction}

The Oxford English Dictionary defines a hotel as an enterprise where travelers, tourists or customers can get services related to accommodation, meals, and other services. According to Olga (2017) the beginning of hotel industry goes back to customs of different places which dates long ago such as Greek and Roman customs. The rise in government officials travelling in different places resulted in building hotels in many small towns to accommodate the officers and other travelers.

Another factor which contributed to rise of hotels in early ages was the coming up of Christianity which attributed to increase for bed and supper to the travelers and especially those going to the religious camps. During that time, small buildings with rooms started mushrooming in Europe which were mostly used as lodgings for pilgrims. The inns became very popular in $17^{\text {th }}$ century, by accommodating travelers, providing something to eat and drink as well as checking their horses and cart tires. The expansion of inns to become more opulence was due to the increase of rich people travelling more and consequently the hotel industry then started to form. The first public hotel opened its doors in 1792 in city of New York under the name of City Hotel. In1829 another luxurious hotel was opened in Boston and named as Tremont House. In 1983, the hotel industry blossomed when people were interested in constructing and buying hotels with one big move of selling Intercontinental Hotels to Japanese Seibu Holdings.

Niewiadomski (2013) emphasized that the meaning of hotel industry actually constitutes independent hotels which are large, medium and smaller sizes and on the other side is the hotels which are branded comprising large chain of hotels in one group. Additionally, Bowie (2016) argued that the 
construction of railway station made people in Britain to travel a lot which lead to demand for hotel services resulting to growth of hotels mostly along the railway, mostly known as railway hotels.

According to Motunrayo (2015), Africa hotel industry has been in existence since the $19^{\text {th }}$ century. Examples are Ethiopia's Taitu built in 1907, Algeria's Saint Georges which has been 'Arabized' to El Djazair hotel built in 1889, South Africa's Oude Werf built in 1687 near Cape Town, Tanzania's Arusha Hotel established in 1894, Kenya's Sarova Stanley launched in 1902 in Nairobi, Nigeria's Federal Palace Hotel established in 1960 in Lagos city, among others. Additionally, Carmody (2013) found that new hotels emerged post-apartheid period which were under chain of hotels.

The private entrepreneurs had dominated the hotel business in Rwanda for a period of time where only independent hotels which were not associated with any branded chain of hotels were found in Kigali city. Information obtained from Rwanda Development Board shows that there are 486 tourism business organizations which provide accommodation and other hotel services. Almost $50 \%$ of these hotel establishments are concentrated in Kigali. In Kigali, there are three five-star and seven four-star hotels. The five-star hotels are Radisson Blu Hotel with 292 rooms, Marriot Hotel with 254 rooms and Serena Hotel with 148 rooms. The four-star hotels are Park inn by Radisson, Lemigo, Hotel des Mille Collines, Ubumwe Grand Hotel among others. The ADR in these hotels are estimated as from $\$ 100$ to $\$ 250$ (Ngabo\&Nibigira, 2018).

Services and revenue earned in hotels classified as four star or five-star is relatively the same, except five-star hotels have more spacious rooms. Five-star hotels tend to have high accommodation rates as well as other services which translates to high volume of revenues (Onyango ,2018). In his study, Vladimir (2012) described the activities in hotel which leads to revenue collection in different hotel centers such as room accommodation, food and drinks, meeting and events, spa and gym and other minor revenues. The success of companies in achieving revenue targets is in most cases attributed to laid down controls in a company. Implementations of Internal control systems have achieved recognition in modern world including the hotel industry.

RDB chief tourism officer,BeliseKariza, announced in the year 2016, the tourism industry generated $\$ 404$ billion in terms of revenue. RDB's chief executive shared a positive development in the industry and challenged operators to improve quality of service, focusing on customer care and experience to generate more revenue (Ndayambaje, 2017).

\section{Review of Literature}

Sirkin (2010) explained that a researcher is required to have a quality theory which can be quantified to produce a good research study which is composed of principles, theories research findings and generations under the study. Different theories exist to guide an inexperienced researcher to prepare a relevant and reliable research project.

\section{Components of Internal Control System}

According to Ngugi (2011) Internal controls system is a combination of functions, procedures and rules which are set in an organization by the management with a purpose of controlling business activities which can deter the organization from achieving its objectives. The committee of sponsoring organization of the Tread way of Commission identified five key elements in a business which make a complete system of internal controls in a business; control environment, risk assessment, control activities, information and communication and monitoring. These five components need to be present and functioning to ensure collection of revenue is maximized in any company (KPMG,2013).

\section{Control environment}

Muhibat(2016)found a significant relationship between revenue generation and internal controls which a business need to recognize as the starting point of achieving its objectives. Earning revenue goes hand in hand with control awareness to relevant stakeholders. It embroils aspects like truthfulness and moral standards of the people charged with crafting, overseeing, as well as evaluating controls, assurance and proficiency of people undertaking delegated jobs , board of directors or audit teams , administration viewpoint and functional approach as well as organizational structure in an organization to enhance revenue collection as targeted by an organization.

Ewa\&Udoayang (2012) asserted that the control environment can be seen to be active in different ways which includes application of ethical codes, training and development of employees, setting policies and procedures that are understandable by the employees, periodical communication to employees, among others. Therefore, control environment is considered to be characterized with the behavior of those given management responsibilities and the employees who follow the tone of the top management towards the running of a business and implementation of a system with sound of internal controls.

In 2013 COSO demonstrated five fundamental principles pertaining to control environment in an 
entity: The company displays dedication to honest, strong moral principles and ethical values; There is separation of independence between the directors and those charged with governance so that appropriate oversight responsibility of controlling systems internally is exercised; The structure of the entity is very effective with proper reporting lines strengthened with authority and responsibilities; Employees are valued by having strategies and plans aimed at the development and retention of competent employees and assigned relevant responsibilities of improving the internal controls of a company. The hotel owners and the management have the responsibility of ensuring there is effective control environment in hotels and all the information is cascaded to the employees. The employees normally see and know how the owners and management react when the laid down controls are not followed.

Managers in businesses are required to identify and asses the risks so that they can develop methods to minimize the risks to an acceptable level within the organization. These methods are guidelines, systems and a course of action established to make sure administration's instructions are correctly undertaken. Proper and correct records of guidelines assist to establish the manner that control undertakings ought to be implemented. It similarly gives an auditor sufficient material for the general appropriateness of controlling the structure of managing the financial affairs of an organization (Aikins, 2011).

According to Muraleetharan (2013), it is imperative a business to have policies and procedures that ensure management directives are carried out as outlined in achieving business objectives. The efficiency of revenue collection in a business can be improved by implementing control activities which decreases errors and manipulation as well as capturing frauds done by employees. The control activities should be able to determine cases where management overrides its own controls to give way to revenue leakage. Further reference is made, citing the suggestion that organization should safeguard its assets and maintain information confidentiality. Systems should be set properly to assure that assets and documents are secured from unauthorized contacts. Different types of access controls are found in different organizations which include key card system, filling cabinets which are locked, physical check, biometric system, data encryption, smart cards, among others. Jackson \& Stent (2012) emphasized that information and communication is an integral component of internal control system and relevant information should be identified and conveyed to parties involved within the organization at the right time and in a right format to enable the users of the information act accordingly. It is necessary that information within an organization is prepared in a documented format with clear understandable languages and subsequently distributed to all staff so that they are aware of their responsibilities and how those responsibilities affect other stakeholders within the organization.

The Committee of Sponsoring Organizations of the Treadway Commission (2013) reiterated that structured or unstructured data is essential for the entity to carry out internal control responsibilities to support the achievement of its objectives. Management generates and uses relevant and quality information from both internal and external sources to support the functions of internal control. Communication is the continual, iterative process of providing, sharing, and obtaining necessary information.

Successful hotels use information technology to integrate the revenue recording system. Therefore, there is a remarkable connection joining revenue collection and information and communication in hotels which ensures that the relevant stakeholders receive information in a timely manner to make informed decisions related to revenue.

Carrier (2017) wrote that revenue collected in a hotel forms a key denominator in decision makingof the operations of the hotel. The hotel management calculates the RevPAR to compare its performance with competitors in the region. The hotel employees are also keen on the revenue collected since there are incentives paid to employees based on the revenue generated. Service charge which is paid to employees is also based on a percentage of the revenue collected in a month.

The hotel mark ups are low when compared to the amount paid by the guest through OTA bookings due to the associated costs such as travel agent commissions. There is still a long way to go as far as management of revenue collection in hotels is concerned. Hotels have resorted to use revenue management software to maximize their yield. The main work of managing revenue collection inhotels is under the responsibility of a revenue manager. The revenue manager uses three main revenue management levers to optimize hotel revenue, namely price, yield and marketing. The revenue manager has to track the KPIs such as occupancy rate, ADR, RevPAR, TrevPAR, NRevPAR, and GOPPAR to develop a strategy for revenue and business success.

Mandelbaum (2018) argued that guest preference impactedtotalrevenue of a hotel. In his study which included U.S.A Hotels, foodrevenues earned in hotel restaurants and lounges lags behind due to consistent preference of guests to relish a more communal, less formal and quicker dining experience. However, revenue from sale of alcoholic beverages showed a rising trend. The government regulatory authorities may have effect on revenue collected in hotels. Oxford Economics through their study on tax policy 
changes in America hotels showed that tax cuts provide stimulus to the economy and are expected to generate a boost to hotel industry revenue due to guest spending. Introduction of a new tax on hotel services results to revenue reduction and vice versa. Vladimir (2012) asserted that revenue collection in hotels take place in different revenue centers in the hotel. The main revenue centers are rooms division, food and drinks departments which provide accommodation and various types of food and drinks to the customers. Revenue is also earned from Spa \& Gym facilities which offer services such as massage and body fitness. The additional revenue can also come from such services like casino services and golf course operations. The hotel evaluates its performance by comparing the revenues earned in different periods of the year.

According to Starkov (2018) the hotel net room revenue (revenue remaining with hotel after accounting for agency commissions) decreased drastically over the last number of years. Hotels in U.S.A paid an approximated amount of $\$ 25.2$ billion to OTA as commissions to receive guests in comparison to estimated revenue of $\$ 155.2$ earned in the year 2017. The hotels saw increase in RevPAR due to overall increase in occupancy for the last couple of years, however, the costs of acquiring the guests via OTA was increasingly high reducing the wealth of the hotels. These OTA costs have prompted hoteliers to look into other avenue such as leaving customers to book hotel services directly. Mu-chun\& Su-yun (2015) in their study asserted that in hotel industry, Marriot Corporation was the first hotel business to implement RM system where Marriot Hotel Group achieved a huge success through use of RM technology in 1991.

Daud\&Laque (2016) argued that employee fraud significantly reduces hotel revenue. The main areas of revenue fraud being stealing of product, embezzlement of money at the selling points by having fiction void checks, false refunds, wrong coupon redemption, inflated discounts or through employee collusion to hide revenue earned.

Tabaro (2019) in his article said that the RDB Deputy chief operating officer, Mr. Zephanie Niyonkuru argued that due to ranking of hotels and subsequent increase in 5-star hotels in Rwanda, the revenue from MICE shoot up from US\$33 million in 2014 to US\$55 million in 2018. Therefore, the government of Rwanda is committed to providing support that leads to the improvements in quality standards of hotels.

The researcher noted that revenue collection in hotel industry is achieved through internal control of cash sales, credit card sales and credit sales. In order to eradicate revenue leakage, the hotel management ensures that the following strong internal controls are Table 3.1 distribution of sample size in place; the cashiers are provided with floats and are required to prepare or print reports which shows transaction for each shift, the cash collected is deposited in a main cash deposit by the cashier accompanied by a witness who also signs a report to show that cash has been deposited. A daily report indicating cash, credit cards, cheques collected from the selling points and highlighting any discrepancy against the system reports is prepared by the general cashier and reviewed by a senior accountant.

The general cashier ensures that all cash collected is deposited to the bank accounts which belong to the hotel on daily basis. The Income Auditor verifies that all money collected by the general cashier has been deposited to the hotel bank account and bank reconciliation is done to ascertain that money is intact in the hotel bank accounts. The credit control manager ensures that credit cards reconciliation is done on daily basis and credit limits are adhered to.

\section{Materials and Methods}

The researcher used the cross-sectional design which consisted of qualitative and quantitative methods to give inferential statistics. Cross-sectional design attempts to show how revenue collection is influenced by the internal control system process implemented in hotel businesses in Kigali. According to Fassinger\& Morrow (2013) the qualitative approach supplemented the quantitative paradigm by providing detailed information to carry out in-depth analysis.

\section{Target Population}

According to Cox (2010) target population for a study is the entire set of units for which the study data are used to make inferences. Target population is a complete accumulation of respondents that meet the selected set of criteria which must be identified and agreed.

The researcher purposely selected a target population of 101 individuals where 51employees were selected from Marriot hotel and 50employees from Lemigo hotel targeting to receive reliable data from employees who are functionally involved in revenue collection and implementation of internal control system process in hotel industry.

\section{Sample Size}

The sample size was estimated using the Slovin's formula indicated as $\mathrm{n}=\mathrm{N} /\left[1+\mathrm{N}(\mathrm{e})^{2}\right]$, where $\mathrm{n}$ is the sample size, $\mathrm{N}$ is the target population size and $\mathrm{e}$ is the margin of error of 0.05 . A sample size of 69 individuals was derived as $\mathrm{n}=101 /\left[1+101(0.05)^{2}\right]=$ 69 as illustrated in table 3.1 and derived from the indicated formula: 


\begin{tabular}{|c|c|c|c|c|}
\hline Position & Target Population & Sample Size & Lemigo & Marriot \\
\hline Food \& Beverage Managers & 4 & 2 & 1 & 1 \\
\hline Accountants & 4 & 4 & 2 & 2 \\
\hline Revenue Manager & 2 & 2 & 1 & 1 \\
\hline Human Resources Manager & 2 & 2 & 1 & 1 \\
\hline Front office Manager & 2 & 2 & 1 & 1 \\
\hline Security Manager & 2 & 2 & 1 & 1 \\
\hline Executive Chef & 2 & 2 & 1 & 1 \\
\hline Income Auditor & 2 & 2 & 1 & 1 \\
\hline Food \& Beverage supervisors & 4 & 2 & 1 & 1 \\
\hline Bartenders & 10 & 8 & 4 & 4 \\
\hline Waiter/Waitress & 20 & 10 & 5 & 5 \\
\hline Cooks & 5 & 2 & 1 & 1 \\
\hline Restaurant Cashiers & 10 & 8 & 4 & 4 \\
\hline General Cashier & 2 & 2 & 1 & 1 \\
\hline Receptionists & 5 & 4 & 2 & 2 \\
\hline Food \& Beverage Controllers & 4 & 3 & 1 & 2 \\
\hline Credit Controllers & 4 & 4 & 2 & 2 \\
\hline Sales Managers & 5 & 2 & 1 & 1 \\
\hline Reservations clerks & 4 & 2 & 1 & 1 \\
\hline Spa \& Gym Attendants & 6 & 2 & 1 & 1 \\
\hline Total & 101 & 69 & 34 & 35 \\
\hline
\end{tabular}

\section{Source: Researcher (2020) Sampling Technique}

The researcher used purposive sampling technique which was effective in ensuring that data collection was obtained across participants who had knowledge of required information pertaining to revenue collection and internal control system in hotel business. Mugenda and Mugenda (2003) defined purposive sampling as a technique which allows the researcher to use cases that have the required information depending on the objectives of the researcher. This technique assisted the researcher to gather reliable information from the respondents' answers since the respondents had relevant information of the research carried out. The purposive sampling focusses on a population with common characteristics which meet the specific interest of the researcher.

\section{Data Collection Methods}

Data collection is the process of gathering and measuring information on variables of interest in a systematic fashion that enables one to answer stated research questions, test hypothesis and evaluate outcomes. The data collection component of research is common in all fields of study. The researcher preferred to use the primary data collection method. This method ensured that data was gathered directly from the respondents through the questionnaires.

\section{Data Collection Instruments}

A questionnaire was administered as a device to gather data. The questionnaire was semi-structured which means it provided questions which were open and closed ended to gather reliable answers. 


\section{Procedures of Data Collection}

The study used structured questionnaire to collect data targeting both managers and other employees who are functionally involved in internal control system process on revenue collection. Further information not provided on the closed-ended questions was obtained through the flexible questions which gave the respondents an opportunity to provide further explanations. The researcher personally administered the questionnaires to have a reliable primary data collection exercise.

Table 4. 1: Questionnaire Response Rate

\section{Results and Discussion} 4.1. Demographic Characteristics of Respondents The respondents who returned their questionnaire were classified in terms of their gender and the number of years they have worked with the selected hotels. The researcher gave out sixty-nine (69) questionnaires out of which fifty-four (54) respondents returned back the questionnaires which represented $78 \%$ of the sampled target population as noticed in table 4.1 .
Category
Frequency

54

15

22

Total
69

100

\begin{abstract}
Source: Primary data (2020)
The response rate was found to be fit as supported by Mugenda and Mugenda (2003), who reported that any response rate above $50 \%$ is considered adequate for research analysis.
\end{abstract}

\section{Gender Composition of the Respondents}

The researcher classified the respondents according to their gender, which resulted to 37 malesand 17 females translating to $68 \%$ and $32 \%$ respectively as represented in figure 4.1 . 


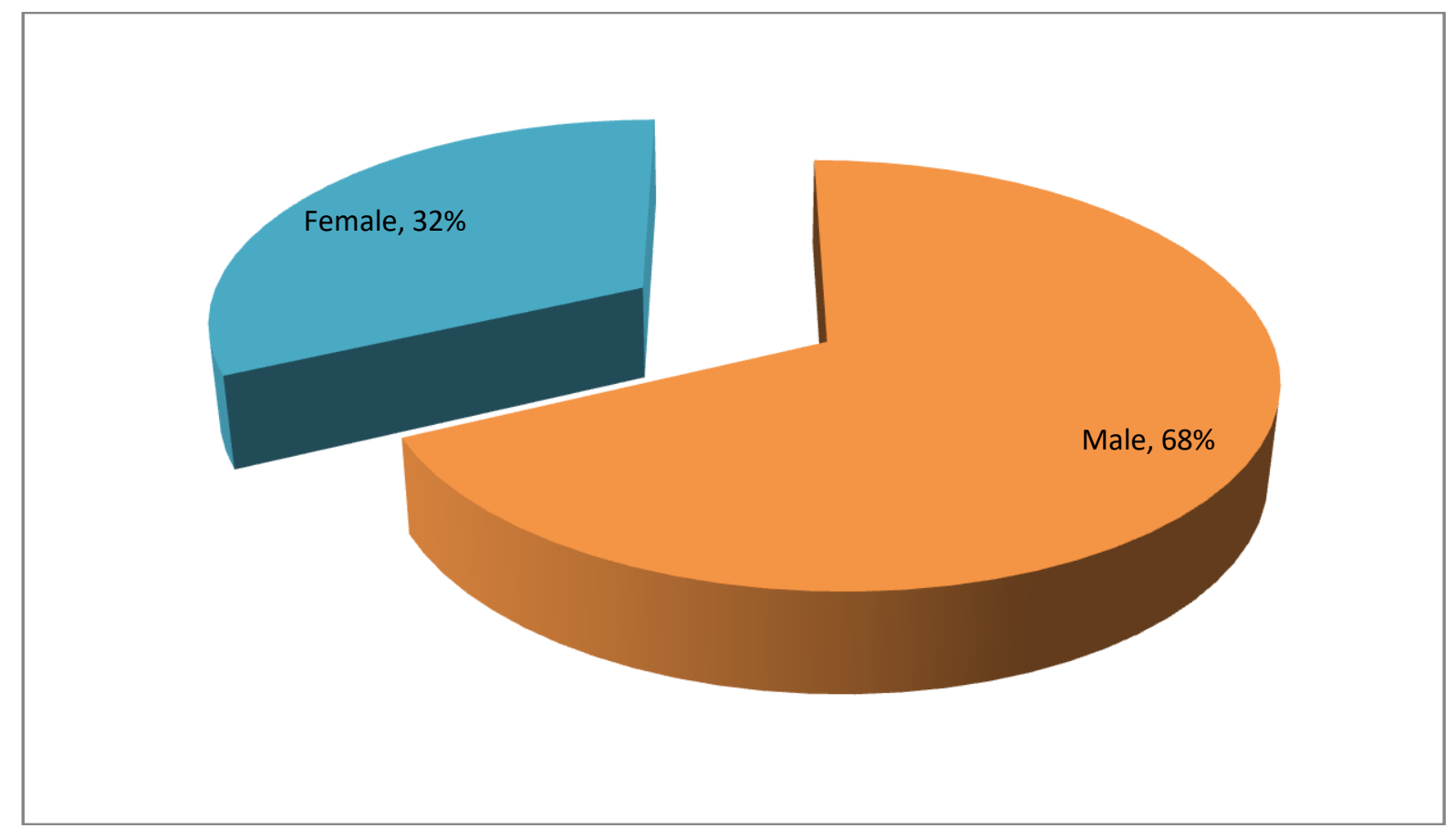

Source: Primary data (2020)

Figure 4. 1: Gender Composition of the Respondents

The data collected showed that male employees were more than twice female employees in the hotel industry in Rwanda.

\section{Years of service of the respondents}

Figure 4.2 illustrates the classification of the respondents according to the length of servicethey have been in employment with the hotel. The survey established that greater number of the respondents wereemployed for a period of one year to five years translating to $61 \%, 26 \%$ worked at the hotel for less than one year, while $13 \%$ of the respondents were in employment for more than one year.

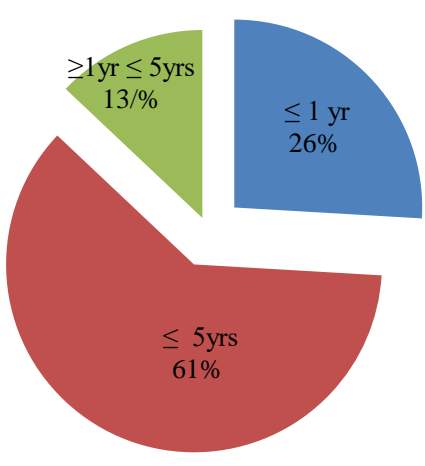

Source: Primary data (2020)

Figure 4. 2: Years of Service of the Respondents

The study sought to understand how many years the employees had worked with the hotel. The data implied that a large percentage $(61 \%)$ of the employees had attained a level of sufficient work experience, between one year and five years, to influence internal control system and revenues collection in hotel industry in Rwanda. It was also evident that very few employees had worked for more than five years (13\%) which reflects the evolvement of hotel industry in Rwanda in particular properties managed by international chain of hotels, 
for example Marriot hotel Kigali was opened in 2016.

\section{Information and communication effect on revenue collection}

Table 4.4pointed out that the highest mean value was, 3.22 which corresponded to Likert scale value of 3 which supports that the respondents agreed that the human resource department has policies and procedures to communicate and identify any deviations in hotel industry in Kigali, Rwanda. The lowest mean value was 1.78 , illustrating that significant number of respondents disagreed that changes in prices of goods and services provided in the hotel is communicated to all relevant stakeholders. Over $30 \%$ of respondents agreed that hotels had computerized accounting systems which is integrated to enhance quality of controls on revenue collection.

Table 4. 2: Information and communication and revenue collection

\begin{tabular}{|c|c|c|c|}
\hline Information and Communication & $\mathrm{N}$ & Mean & $\begin{array}{c}\text { Std. } \\
\text { deviation }\end{array}$ \\
\hline 1.There is computerized system to record transactions & 54 & 2.15 & 0.960 \\
\hline 2.All system users have passwords to $\log$ in to systems & 54 & 2.20 & 1.122 \\
\hline $\begin{array}{l}\text { 3. The Human resource department has policies and procedures to } \\
\text { communicate and identify any deviations. }\end{array}$ & 54 & 3.22 & 1.283 \\
\hline $\begin{array}{l}\text { 4.Changes in prices of goods and services providedin the hotel is } \\
\text { communicated to all relevant stakeholders }\end{array}$ & 54 & 1.78 & 0.883 \\
\hline $\begin{array}{l}\text { 5. The system data and information are safeguarded against misuse } \\
\text { either internally or externally }\end{array}$ & 54 & 2.48 & 1.342 \\
\hline
\end{tabular}

Source: Primary data (2020)

It is evident that selected hotels in Kigali had established communication channels to employees through the human resources department. However, there is lack of full implementation of information dissemination with regard to revenue collection.

\section{Table 4.3: Revenue collection}

\begin{tabular}{|c|c|c|c|}
\hline Revenue collection & $\mathrm{N}$ & Mean & $\begin{array}{c}\text { Std. } \\
\text { deviation }\end{array}$ \\
\hline 1. Control activities have effect revenue collection & 54 & 3.41 & 1.301 \\
\hline $\begin{array}{l}\text { 2. Proper communication and adequate information is essential when } \\
\text { revenue collected by credit cards. }\end{array}$ & 54 & 3.33 & 1.303 \\
\hline 3. There is need to assess the risks associated with credit sales. & 54 & 3.57 & 1.109 \\
\hline $\begin{array}{l}\text { 4. Performing risk assessment reduces errors and frauds related to cash, } \\
\text { credit cards and credit sales. }\end{array}$ & 54 & 3.67 & 1.318 \\
\hline $\begin{array}{l}\text { 5. Proper communication from the hotel management to relevant } \\
\text { stakeholders is key to revenue collection. }\end{array}$ & 54 & 3.61 & 1.106 \\
\hline
\end{tabular}

\section{Source: Primary data $(2020)$}

The results of mean and standard deviation in table 4.5 illustrated that performing risk assessment reduced errors and frauds affecting revenue by a mean score of 3.67 while need for proper communication and adequate information had a 
mean score of 3.33 when revenue collection is transacted through cash, credit and credit cards sales.

\section{Effect of internal control system process on} revenue collection

The researcher conducted data analysis to explore the correlation between the internal control system components and the revenue collection in selected hotels in Kigali, Rwanda. The results of the analysis are illustrated in tables 4.5, 4.6,4.7 and 4.8.

\section{Relationship between internal control system process and revenue collection}

The correlation between the indicators of the internal control system process and revenue collection produced the output as indicated in tables 4.5, 4.6, 4.7, and 4.8.

Table 4. 4: Model summary

\begin{tabular}{|c|c|c|c|c|}
\hline \multirow[b]{2}{*}{ Model } & \multicolumn{3}{|c|}{ Model Summary } & \multirow[b]{2}{*}{$\begin{array}{l}\text { Std. Error of the } \\
\text { Estimate }\end{array}$} \\
\hline & $\mathrm{R}$ & R Square & $\begin{array}{c}\text { Adjusted R } \\
\text { Square } \\
\end{array}$ & \\
\hline 1 & $.966^{\mathrm{a}}$ & .933 & .732 & .074 \\
\hline
\end{tabular}

Source: Primary data (2020)

The results in table 4.6 exhibited $\mathrm{R}$ square of 0.933 , an indication that $93.3 \%$ of the deviations in revenue collection of hotels in Kigali are caused by changes in control activities, risk assessment and information and communication. The other elements not involved in the model represented $6.7 \%$.

Table 4. 5: Analysis of Variance (ANOVA)

\begin{tabular}{|c|c|c|c|c|c|c|}
\hline \multicolumn{7}{|l|}{ ANOVA } \\
\hline Model & & Sum of Squares & df & Mean Square & $\mathrm{F}$ & Sig. \\
\hline \multirow[t]{3}{*}{1} & Regression & 0.0758 & 3 & 0.0253 & 4.644 & $0.3258^{b}$ \\
\hline & Residual & 0.0054 & 1 & 0.0054 & & \\
\hline & Total & 0.0813 & 4 & & & \\
\hline \multicolumn{7}{|c|}{ a. Dependent Variable: Revenue Collection } \\
\hline
\end{tabular}

\section{Source: Primary data (2020)}

The analysis of variance (ANOVA) illustrated a regression pattern which was not significant because F statistics value was insignificant at $95 \%$ confidence level since the $\mathrm{p}$-value $(0.3258>0.05)$. These figures suggested there is no significant relationship between independent variable elements of information and communication, risk assessment effectiveness, control of activities and the dependent variable revenue collection. 
Table 4. 6: Regression Coefficients

\begin{tabular}{lcccc}
\hline & Coefficients & Standard Error & $t$ & Sig. \\
\hline (Constant) & 4.214418 & 0.474534 & 8.881168 & 0.071381 \\
Control activities & -0.33363 & 0.102368 & -3.25914 & 0.189529 \\
Risk assessment & 0.153844 & 0.076549 & 2.009747 & 0.293931 \\
& & & & \\
$\begin{array}{l}\text { Information and } \\
\text { communication }\end{array}$ & -0.02335 & 0.077822 & -0.30002 & 0.814439 \\
\hline
\end{tabular}

a. Dependent Variable: Revenue Collection

Source: Primary data (2020)

Table 4.8showed tha trisk assessment produced a positive result although not a statistically significant relationship with revenue collection where $r=$ $0.1538, p=0.2939$. Control activities had a negative non-statistically relation with revenue collection where $r=-0.3336, p=0.1895$ and information and communication produced a negative non-statistical relationship of $\mathrm{r}=-0.0234$ and $\mathrm{p}=0.8144$. The following regression equation was estimated: $Y=4.214-0.334 X_{1}+0.154 X_{2}-0.023 X_{3}$ where:

$\mathrm{Y}=$ Revenue collection of selected hotels in Kigali,

Rwanda.

$\mathrm{X}_{1}=$ Control activities

$\mathrm{X}_{2}=$ Risk assessment

$\mathrm{X}_{3}=$ Information and communication.

The results from the regression equation indicated that if the variables which are independent (control activities, risk assessment and information communication) were put to zero, revenue collection of selected hotels would be 4.214. A decrease in control activities by one unit would decrease revenue collection of selected hotels by 0.334 , representing $33.4 \%$.An increase of an element in risk assessment would trigger an increase of revenue collection by 0.154 , representing $15.4 \%$. Similarly, a decrease in one unit of information and communication would result in a decrease of revenue by 0.023 , representing $2.3 \%$.Table 4.8 demonstrated that the Sig. value for

\section{Conclusions}

There is a general knowledge for hotel businesses to gauge the attribute of its internal control system so as to help the operators and owners of hotels to verify the success of the system, and its importance towards value addition to the hotel. Overall, the selected hotels indicated that the units of internal control system in relation to revenue collection were in place. However, some improvements are needed to enhance efficiency and effectiveness of both internal control system process and revenue collection. Large numbers of businesses have embraced logistic all dependent variables is more than the alpha of 0.05 , meaning that independent variables do not significantly affect revenue collection in hotel industry in Kigali, Rwanda.

Further, the researcher found a significant positive relation between control activities, risk assessment and information communication revenue on collection in hotel industry in Kigali. This meant that control activities had a direct effect on revenue collection in hotel industry in Kigali. Control activities coefficient of 0.334 is not remarkably dissimilar from 0 because its p/value is 0.154 which is larger than 0.180. Meaning control activities has significance and positively influences revenue collection in hotel industry in Kigali. The intercept is notably dissimilar from 0 at the 0.05 alpha level.

The findings also showed that risk assessment had a direct impact on revenue collection in hotel industry in Kigali hence an increase in risks assessment increases revenue collection. Finally, the results indicated that information and communication negatively influenced revenue collection in hotel industry in Kigali but the relationship was insignificant to cause any impediments on revenue collection. It was evident that an inverse interrelationship occurred between revenue collection and information and communication and control activities whereas a decrease in risk assessment would reduce revenue collection in hotel industry in Kigali.

regression to gauge the efficiency of internal control system.

The regression analysis was utilized to explore the effects of multiple variables on given dependent variables where the study established that not every single internal control system component had statistical positive relationship to revenue collection in hotels in Kigali, Rwanda. It was evident that control activities and information and communication system had negative statistical effect of -0.334 and -0.0234 respectively which implied that a unit decrease in control activities and information and communication lead to a unit decrease in revenue collection. The risk assessment 
indicator produced a positive effect on revenue collection of 0.154 which implied that an increase of an element in risk assessment would lead to an increase in element of revenue collection. The model summary exhibited that the predictors of internal control system had $93.3 \%$ of the changes on the revenue collection as depicted by the value of $R$ squared which indicated that the factors missing on the model was $6.7 \%$ of changes on revenue collection.

Conclusively, the process of internal control system of the hotel enterprise was found to be sound with aim of achieving the targets of revenue collection. Nevertheless, there were notable aspects of ineffectiveness concerning the execution of internal control system in hotel enterprises which need improvement. Segregation of duties and supervision on revenue collection indicated a challenge to improve the control activities. Information and communication were an area which was not adequately embraced leading to errors and frauds in revenue collection. It was evident that performing risk assessment would reduce errors and frauds related to revenue collection done through cash sales, credit card sales and credit sales

\section{Acknowledgments}

I wish to acknowledge Dr. Claude Rusibana (PhD) for his contribution to this work from the beginning up to its completion. I extend my acknowledgement to the Lemigo hotel and Marriot hotel authorities for their support and cooperation during this study.

\section{Reference}

[1] Addey, J. (2012). An assessment of internal control system on the image of the hospitality industries in Royal Mac-Dic Hotel and Capital Hill Hotels. Kwame Nkrumah University.

[2] Aikins, S.K. (2011). An examination of government internal audit's role in improving financial performance. Public Finance and Management, 11(4), 306-337.

[3] Akintoye, A. (2015). Developing theoretical and conceptual frameworks. EDMIC 2015 Research workshop, OAU,IleIlfe, Nigeria.

[4] Bowie, D. (2016). Pure diffusion? The Great English Hotel Charges Debate in The Times, 1853. Business History, 58(2), 159 - 178.

[5] Carrier, M. (2017), Kalibri Labs. Accounting for the gap between guest-paid, hotelcollected revenue and COPE revenue.

[6] Charles, Mark, Nick, \&Stathis (2012). Business model, International Integrated Reporting council, IISN, 2052-1723.

\section{ISSN 2455-6378}

[7] Cherutich, K.B (2018). 'The effect of Internal Controls on the financial performance of three-star hotels in Nairobi county', MBA Project, University of Nairobi.

[8] Cetin, L. (2017). "Measuring service quality. A review and critique of research using servqual". International Journal of Market Research, Vol. 46(4), pp. 479-497.

[9] Cox, B.G. (2010). "Research methods.", Encyclopedia of Survey Research Methods: ISBN;978141

[10] Daud, W.\&Laque, P. (2016). Ten ways to prevent fraud by restaurant employees. Nation's Restaurant News.

[11] Drost, E. A. (2011). Validity and reliability in social science research. Education Research and Perspectives, 38 (1), 105-124.

[12]Eke, P. (2018). Public-service motivation: Building empirical evidence of incidence and effect. Journal of Public Administration Research and Theory. Vol. 6 (2), pp. 499518.

[13] Ewa, E.U. \&Udoayang, J.O. (2012), “The impact of internal control design on banks' ability to investigate staff fraud, and life style and fraud detection in Nigeria", International Journal of Research in Economics \& Sciences.

[14] Fassinger, R., \& Morrow, S. (2013) Toward best practices in quantitative, qualitative and mixed-method research: a social justice perspective. Journal for Social Action in Counselling and Psychology, 5(2), 69-83.

[15] Foster, P.L. (2019). COSO internal control integrated framework: An Implementation Guide.

[16] Frazer, S. (2012). Effects of internal controls on restaurant operating activities. Journal of Business and Economics, 10(6).

[17] Freeman, R.E. (2010). Managing for stakeholders: Trade-offs or value creation. $J$ Buss Ethics 96:7-9

[18] Gahigi, M. (2018, June 04). Hotel entrepreneurs in Rwanda were facing closure of business due to low revenues. Rwanda Today Newspaper. Retrieved from http://www.rwandatoday.com

[19] Gupta, M. (2019). Hotel revenue management-revenue controls \& income audit

process.https://www.icpsr.umich.edu/ICPSR/ prize/lista.pdf

[20] IFAC, K. (2012). The determinants of service quality satisfiers and dissatisfies. International Journal of Service Industrial. Manage. Vol 6(5), pp. 353-71. 
[21] Jackson,R.D., \&Stent,W.J. (2012). Auditing notes for South African students ( $8^{\text {th }} \mathrm{ed}$.). South Africa: LexisNexis.

[22] KPMG. (2013). 2750-New-COSO-2013 Framework - WHITEPAPER- V4.1-8.

[23] Lista, P., Advisor, F. \& Rojas, F. (2014). Contingency in organizational behavior

[24] Mandelbaum, R. (2018). CBRE'S annual trends in the Hotel Industry survey of U. S. hotels.

[25] Mitchell, R., \&Meacheam, D. (2011). Knowledge worker control: Understanding via principal and agency theory. The Learning Organization, 18(2), 149-160. https://doi.org/10.1108/09696471111103740

[26] Motunrayo, S. (2015). Historic hotels in Africa: Jumia Food Blog Uganda.

[27] Mu-chun, L\& Su-yun, M.A. (2015). Hotel revenue management performance. South China University of Technology, Wuhan International conference: Summer 19-62015.

[28] Mugenda, O.M.\& Mugenda, A. G (2003). Research methods: Quantitative and qualitative approaches. Nairobi: African Centre for Technological studies. (ACTS).

[29] Muhibat, A. O. (2016). The impact of internal control system on revenue generation in public establishment. International journal of Contemporary Applied Sciences, 3 (8).

[30] Muraleetharan, P. (2011). Internal control and impact of financial performance of the organizations (special reference public and private organizations in Jaffna district). International Conference on Business \& Information (C/OL).

[31] Ndayambaje, R. (2017). Rwanda hotels awarded star classification licenses. The New Times, 26 October,2017.

[32] Ngabo, R.\&Nibigira, C. (2018). Horwath HTL Rwanda. Market report - December 2018, (pp.6-8)

[33] Ngugi, K.M. (2011). A survey of internal control systems among the listed private companies and the public sector companies in Kenya. Unpublished Research Thesis. University of Nairobi.

[34] Niewiadomski, P. (2013). The globalization of the hotel industry and the variety of emerging capitalisms in Central and Eastern
ISSN 2455-6378

Europe. European Urban and Regional Studies, DOI: 10.1177/0969776413502658.

[35] Olga, R. (2017). Global business travel association. A brief history of hotels. Organization decision-making and the market environment: Examining principal and agency theory" The Learning Organization, Vol. 18 No. 2, pp.149-160

[36] Reilly, K. (2015). The five-letter f word: Fraud in the hospitality industry; HFTP Annual Convention Seattle Washngton, October 24.

[37]Robison, A. (2011). Frameworks for determining gaps during systematic reviews. Johns Hopkins University, HHSA 290-20071006-1.

[38] Shah, S. (2018). Combating fraud in the hospitality industry.Berdon Industry Insights.BerdonLLP , New York Accountants ,20 february,2018.

[39] Sirkin, R. (2011). New strategic tools for supply chain management, International Journal of Physical Distribution \& Logistics Management, Vol.21 No.1, pp.23-33.

[40] Starkov. A. (2018). Absorptive capacity: A new perspective on learning and innovation. Administrative Science Quarterly, Vol. 34(4), pp. 128-152.

[41] Steinberg, R. (2010). Principal - agent theory and nonprofit accountability. In K.J. Hopt\& t. Von Hippel (Eds.), Comparative Corporate Governance of Non-Profit Organizations(pp.73-125). UK: Cambridge University Press.

[42] Tabaro, C. (2019). Hotels ranking. Bisate Lodge completes list of Rwanda's big five. KT Press, November $02,2019$.

[43] Theofanis, K., G.\&Giovanis, N. (2011). Evaluation of the effectiveness of internal audit in Greek hotel business. International Journal of Economic Sciences and Applied Research, 4(1), 19-34.

[44] TripAdvisor (2018, September 06). Very bad management. Review of StippKiyovuHotel.TripAdvisor. Retrieved from http://www.tripadvisor.com

[45] Vladimir, S.Z. (2012). Hotel revenue management. International University College, Dob rich, Bulgaria, Vol.60/No.2/175-197. 